\section{$\frac{91 / 5^{16}}{26^{-1}}$ ANCR-1155}

$\frac{3}{3}$
Wo stack s

UC-13

\title{
IDAHO GEOTHERMAL $R$ \& D PROJECT REPORT FOR PERIOD \\ DECEMBER 16, 1973 TO MARCH 15, 1974
}

SUBMITTEO TO THE IDAHO OPERATIONS OFFICE

AND THE DIVISION OF APPLIED TECHNOLOGY

BY THE GEOTHERMAL PROJECT

Prepared by:

J.F. Kunze

L.G. Miller

\section{Aerojet nuclear Company}

NATIONAL REACTOR TESTING STATION

Idaho Falls, Idaho -8340 I

MARCH 18, 1974

PREPARED FOR THE

U. S. ATOMIC ENERGY COMMISSION

IDAHO OPERATIONS OFFICE UNDER CONTRACT AT(10-1)-1375 


\section{DISCLAIMER}

This report was prepared as an account of work sponsored by an agency of the United States Government. Neither the United States Government nor any agency Thereof, nor any of their employees, makes any warranty, express or implied, or assumes any legal liability or responsibility for the accuracy, completeness, or usefulness of any information, apparatus, product, or process disclosed, or represents that its use would not infringe privately owned rights. Reference herein to any specific commercial product, process, or service by trade name, trademark, manufacturer, or otherwise does not necessarily constitute or imply its endorsement, recommendation, or favoring by the United States Government or any agency thereof. The views and opinions of authors expressed herein do not necessarily state or reflect those of the United States Government or any agency thereof. 


\section{DISCLAIMER}

Portions of this document may be illegible in electronic image products. Images are produced from the best available original document. 
Printed in the United States of America

Available from
National Technical Information Service

U. S. Department of Commerce

5285 Port Royal Road

Price: Printed Copy $\$ 4.00 ;$ Microf \pm che $\$ 0.95$

\section{LEGAL NOTICE}

This report was prepared as an account of work sponsored by the United States Government. Ne ither the United States nor the United States Atomic Enetgy Commission, nor any of their employees, nor any of their contractors, subcontractors, or the ir employees, makes any warranty, express or implied, or assumes any legal liability or responsibility for the accuracy, completeness or usefulness of any information, apparatus, product or process disclosed, or represents that its use would not infringe privately owned rights. 
TID-4500

IDAHO GEOTHERMAL RED PROJECT REPORT FOR PERIOD 12-16-73 TO

\section{$3-15-74$}

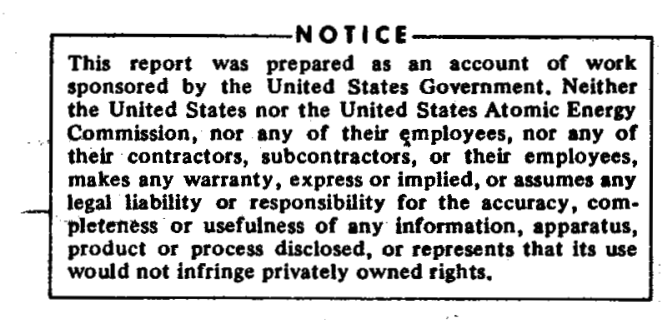

Prepared by: J. F. Kunze

L. G. Miller

SUBMITTED TO THE IDAHO OPERATIONS OFFICE AND THE DIVISION OF APPLIED TECHNOLOGY

BY THE GEOTHERMAL PROJECT

March 18, 1974

AEROJET NUCLEAR COMPANY

Prepared for the U.S. Atomic Energy Commission

Idaho Operations Office

Under Contract No. AT (10-1)-1375

ง 


\section{ABSTRACT}

The Idaho Geothermal R\&D Project was initially charted by the Division of Applied Technology in December 1973. This report covers the first three months of activity. A brief summary is given in Section 2, with more detailed discussions in subsequent sections. 
1.0 BACKGROUND INFORMATION ................. 1

2.0 BRIEF SUMMARY. . . . . . . . . . . . . . 4

3.0 GEOLOGY AND GEOPHYSICS . . . . . . . . . . . . . 5

4.0 POWER CYCLE STUDIES AND POWER PLANT DESIGN . . . . . . . 7

4.1 Steam Plant Sizing .............. 7

4.2 Down Hole Pumps. . . . . . . . . . . 8

4.3 Condenser Cooling Source.............. 8

5.0 PLANS FOR SUBSEQUENT QUARTER ................ . 9

APPENDIX I . . . . . . . . . . . . . . . . 24

APPENDIX II . . . . . . . . . . . . . . 35

\section{FIGURES}

1. USGS February 1, 1974, Open-File Geology Map of Southern Part of Raft River Valley. Bridge bolling wells just off bottom of map ... . . . . . . . . . . . . . 10

2. USGS February 1, 1974, Open-File Geology Map of Raft River Valley West Side, Cotterrel and Jim Sage Range, and Almo Basin. Bolling wells located in T15S, R26E, S23, 1-1/2 miles south of bottom right-corner of map................ 11

3. USGS February 1, 1974, Open-File Geology Map of Extreme Southern Part of Raft River Valley. Bolling Wells just west of S24 near upper left corner. . . . . . . . . . . 12

4. USGS February 1, 1974, Open-File Geology Map of Southern Part of Raft River Valley and Almo Basin. Bolling wells in S23 near upper right corner .................. 13 
TABLE OF CONTENTS (Cont' $d$ )

FIGURES (Cont'd)

5. Audio-magnetotelluric Apparent Resistivity at $26 \mathrm{Cycles} / \mathrm{sec}$, North South Iine...................

6. Audio-magnetotelluric Apparent Resistivity at 26 Cycles/sec, East-West Line....................

7. Audio-magnetotelluric Apparent Resistivity at 18,600 Cycles/

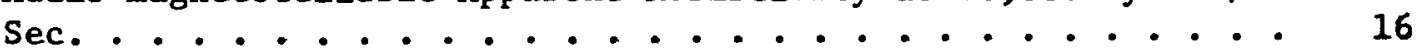

8. Bouguer Gravity Anamoly Contours . . . . . . . . . . 17

9. Residual Magnetic Intensity Contours . . . . . . . . . 18

10. Single flash Rankine cycle energy production from geothermal water of four different temperatures. Condenser pressure 1.5 in. HgA. No 1osses and $100 \%$ turbine efficiency assumed

11. Single stage steam power plant performance from $300^{\circ} \mathrm{F}$ geothermal fluid .................

12. 10 $M W(e)$ single stage steam flash from $300^{\circ} \mathrm{F}$ geothermal fluid. . . . . . . . . . . . . . . .

13. Geothermal we11 flow increase resulting from down-hole pump. Note: $150^{\circ} \mathrm{C}\left(302^{\circ} \mathrm{F}\right)$ hot water will not pump from well of less than $1,950 \mathrm{ft}$ if saturation pressure (69 psia) is to be maintained at topc of well . . . . . . . . .

14. Geothermal flow increase resulting from down-hole pump. Note: $200^{\circ} \mathrm{C}\left(392^{\circ} \mathrm{F}\right)$ hot water will not pump from well of less than $3,800 \mathrm{ft}$ if saturation pressure (226 psia) is to be maintained at top of well ............. 


\subsection{BACKGROUND INFORMATION}

The area of Southern Idaho is one of the most promising regions within the United States for near surface, economically recoverable geothermal energy. It is identified by geologists as the younger end of a major Volcanic Rift Province. The Raft River Valley is a faulted, north-south trending sedimentary basin intersecting the wajor volcanic rift known as the Snake River Plain. It is in the Raft River Basin that a number of wells, drilled for irrigation purposes, unexpectedly yielded warm to hot water. Two such wells bottoming at 400 and $540 \mathrm{ft}$ yleld bolling water under artesian flow. These wells are near the Malta, Idaho headquarters of the Raft RIver Rural Electrical Cooperative, Inc., an REA financed power company serving $10,000 \mathrm{sq}$ miles of Southcentral Idaho, Northwestern Utah, and Northeastern Nevada.

The occurrence of the bolling water in the Malta, Idaho area promoted the Raft River Rural Electric Cooperative to conduct preliminary geological Investigations pertinent to the possibility of establishing a geothermal power plant in the area for the production of electricity. Simultaneously, the Coop management began securing geothermal leases on the private land owned by its members.

Aerojet Nuclear Company, prime contractor to the U.S. Atomic Energy Comission at the National Reactor Testing Station (40 miles north of the Raft River Electrical Coop. service area), entered Into a preliminary engineering and feasibility study, including assistance in gathering additional geophygical information from the Raft River Valley. 
Unlike the anomalous Geysers hot dry steam field in Northern California, the Raft River Valley is a hot water field (approximately $150^{\circ} \mathrm{C}$ ) very similar to most of the Identified geothermal potential resources in the Northwest. These temperatures are not currently attractive for commerclal production of electric power. Neither the economics nor eyen the most economical power extraction techniques are yet known for these low temperature heat sources. Though the salinity of these waters is generally low (compared to the Cerro Prieto field, for lnstance), still the use of this water has not been mastered for long-term heat exchanger application.

Should further geological and geophysical work confirm the suitability of the Raft River resource for an R\&D project and should funding be made ayailable, the AEC and its contractor will design and install the geothermal plant. Raft Rlyer Rural Electric will arrange for leasing of the priyate-land geothermal rights on which it now has an option. The utility will also provide for the electrical connections and use of the power. The AEC will actively monitor and manage the geothermal field, which though highly convectlve exists in a region where ground water supplies have been shown to be quite sensitive to wthdrawal rates. Re-injection of both geothermal and condenser cooling-water (from the cold-water aquifer) is considered a likely necesity.

The Raft River area appears ideal for demonstrating the harnessing of the power producing potentlal in warm, not hot, water. With only $150^{\circ} \mathrm{C}$ water anticipated, conventional steam turbine systems appear onIy marginal for normal applications. But, the Raft River Valley's 
near surface aquifer is quite cold, approximately $10^{\circ} \mathrm{C}\left(50^{\circ} \mathrm{F}\right)$. With such a cold temperature heat sink, $150^{\circ} \mathrm{C}$ water becomes quite attractive, from a Carnot efficlency viewpoint.' A low bolling point organic fluid is a prime candidate for the working fluid, but the economics of it compared to steam has not been established, as yet.

The demonstration power plant will contain a steam and/or a binary (organlc fluid) cycle depending upon flnal temperatures and mineral content of the hot water. Inftial operation of the plant 18 anticipated to be mid-1977. More detalls about the geology of the area, its apparent geothermal potential, and the general characteristics of the various power cycles being considered can be obtained from the report ANCR-1138, entitled "A Low Temperature Demonstration Geothermal Power Plant in the Raft River Valley," dated February 1974.

The overall goals of the profect are basically as follows:

1. To demonstrate the extraction of energy from a hydrothermal field utilizing full re-injection of the waste fluid. The reinjected fluid is to contribute to the fluid re-charge of the hydrothermal field, with minimum environmental degradation and minimum degradiation of the thermal heat source.

2. To demonstrate the design and operational characteristics of a geothermal electric power plant operating from a reservoir temperature well below the limits $\left(170^{\circ} \mathrm{C}\right.$ or $\left.338^{\circ} \mathrm{F}\right)$ now considered to be economically attractive for commercial development. 


\subsection{SUMMARY}

1. U. S. Geological Survey data taken in the fall of 1973 was released to open file on February 1, and has been examined by co-workers at Boise State University. Subsequent geological and geophysical investigations by the USGS are scheduled to resume in the spring of 1974.

2. The shallow well drilling program commenced to study the ground water patterns possibly feeding the geothermal reservoir. As of March 15, 18 holes to a typical depth of $100 \mathrm{ft}$ were completed.

3. Discussions have been held with two drilling companies, and efforts to secure a sufficient quantity of long-lead-time drilling pipe are now underway.

4. Power cycle studies and conceptual design were begun on both low temperature steam flash and low temperature water-to-organicfluid heat exchangers.

5. Contacts have been made with both Utah Power and Light Company and Idaho Power Company to ascertain how this project would best serve utility needs of the future. Also, several vendors of equipment were contacted to determine their interest in the project. 


\subsection{GEOLOGY AND GEOPHYSICS}

The U.S. Geological Survey has open filed the geology and geophysical data obtained in the Raft River Vailey last fall. Reduced copies of the geologic, magnetic, gravity, and automagnetotelluric apparent resistivity data are attached as Figures 1 through 9.* No interpretation of the data has been officially made by the USGS, but some interpretative information is attached as Appendix I, a report by

Dr. Clayton Nichols of Bolse State University working in cooperation with AEC-ANC via funding provided by the Idaho Nuclear Energy Commission.

An agreement for further exploration this fiscal year is presently being negotiated. This agreement between the AEC and the U.S. Geological Survey specifies further geological and geophysical work to be conducted to better define the geothermal field.

The drilling of shallow (100 ft) hydrology wells (5-1/2 in. dia.) through the Raft River Narrows area is progressing satisfactorily with 18 wells completed. Two well positions may have to be rotary drilled due to the large rock encountered at 10 to $15 \mathrm{ft}$ depths. Highest temperature encountered to date was $48^{\circ} \mathrm{C}\left(118^{\circ} \mathrm{F}\right)$ at the bottom of a $30 \mathrm{ft}$ deep and a $40 \mathrm{ft}$ deep wells east of the narrows. Though these shallow holes are intended to study the near surface water flow pattern, temperatures of this magnitude this close to surface also provides clues concerning the circulation of heated water from depth to the surface.

ANC and ID personnel met with NAVOO and REECO personnel on March 4, in Nevada. The drilling rigs were inspected and costs were discussed in detail. They have one rig which could be made avallable. This rig could drill at least $8,000 \mathrm{ft}$. A 20-in. casing through the domestic aquifer with 10-3/4 in. beyond is tentatively planned. From the various information currently available, it would appear that one might plan for drilling to about 1,000 ft, where impermeable basement rock is likely to be encountered. TI5S, approximately centered at coordinates $113^{\circ} 23^{\prime} \mathrm{E}$ longitude and $42^{\circ}$ $06^{\prime}$ 'N latitude. 
Petrological examinations were performed on drilling chips supplied to Boise State University (work sponsored by Idaho Nuclear Energy Commission). Subsequently, drilling records, mud logs, lithology logs, and analysis of the well samples from the two deep oil and gas wells were supplied to REECO well drilling personnel for use in estimating drilling costs in the Raft River Valley. Drilling time was very short (on the order of three weeks) for the Malta (Griffith-Wight) well to $6787 \mathrm{ft.*}$ Time estimates for our first test well should also be short but considerably more logging will be done substantially increasing the actual drilling period. The Boise State University preliminary evaluation is attached as an Appendix I.

AEC (ID) Procurement has agreed to allow the purchase of well casing as a stock item not tied to any program. This will allow the purchase of this long lead time item for delivery by September without tying up FY-74 program funds.

* The two ofl and gas wells were drilled in the fall of 1973 by a commercial gas exploration company. Both wells have since been abandoned. One began to spout hot water three weeks after being abandoned. That flow has since been controlled. 


\subsection{POWER CYCLE STUDIES AND POWER PLANT DESIGN}

Efforts to date have concentrated on system parametric studies with the alm of establishing criteria from which one can arrive at an optimized (minimum) cost system. The work has been largely with the single stage flash steam cycle, but brief studies on the binary (organic fluid) cycle have also been made on heat exchanger design. As for the latter, the results of the preliminary work show that the supercritical fluid cycle (e.g., Freon-12) will involve long counter-flow heat exchangers (over $100 \mathrm{ft}$ ) unless the pinch points are significantly relaxed from the otherwise desired $10^{\circ}$ to $15^{\circ} \mathrm{F}$ value. Relaxing the pinch point to larger values in turn results in less tempexature drop for the geothermal fluid (less heat removed) and lower operating temperatures and efficiencies for the organic fluid turbine.

\subsection{Steam Plant S1zing}

For a given quantity of geothermal flufd, the flash pressure and turbine conditions can be determined. A reduction in flash pressure w11l increase the amount of steam produced, but its temperature will be lower and the available turbine enthalpy will be less. Figure 10 shows parametrically this relationship. Apriori, one might be inclined to accept the maxima of these curves (approximately $88^{\circ} \mathrm{C}$ or $190^{\circ} \mathrm{F}$ steam) for the design conditions. However, by moving off of the maximum to higher temperatures, one finds that the system hardware (piping and turbines) become substantially smaller. For instance, the same turbine operating from $220^{\circ} \mathrm{F}$ has $50 \%$ higher steam throughput than one operating from $200^{\circ} \mathrm{F}$. Yet the $\mathrm{kW}-\mathrm{hr} / \mathrm{lb}$ of brine curve shows only a $3 \%$ reduction in cycle output-a minor penalty for the much smaller turbine.

Such considerations relating to hardware size and hence cost are demonstrated in Figures 11 and 12. It is apparent that high steam rates are not necessarily the desired plant design criteria. Nor, for that matter, is minimum capital cost of the power plant equipment (above ground) for the well cost and geothermal field lifetime are characteristics to be included in the overall cost optimization studies. 
Appendix II shows results of multiple stage steam flash considerations, a parametric study completed under a cooperative support arrangement funded by the Idaho Nuclear Energy Commission.

\subsection{Down Hole Pumps}

Calculations were performed on the feasibility and usefulness of down-hole pumps. Such pumps appear economically justifiable for boosting the output of low temperature, shallow wells, and to restart shut-in wells. For shallow wells, $<2,000 \mathrm{ft}$, the increased flow from pumping will produce, typically, three times the return in electrical output as the pumping power requirements. And, of course, shallow low temperature wells will most liekly require pumping to maintain saturation pressure at the surface and hence prevent flashing until the fluid reaches the plant. At depths less than 5,000 to 6,000 ft, the increased flow from pumping is not impressive compared to overall flow. Pumps in such wells have their principal advantage in starting a well that has been shut-in and whose water column has cooled. Plots for $150^{\circ} \mathrm{C}$ and $200^{\circ} \mathrm{C}$ water wells showing the advantage of down hole pumps are shown in Figures 13 and 14. Note, pumps need not be placed at the well bottom. In general, they need be positioned merely deep enough that the above head is sufficient to prevent flashing and that the below hydrostatic driving force is sufficient to satisfy the net positive suction head requirements of the pump.

\subsection{Condenser Cooling Source}

Preliminary studies on conceptual design and costs estimates of the once-through condenser cooling concept occupied substantial effort. It appears that economic benefits from this concept will be difficult to achieve (compared to wet cooling towers) unless the cold water source is at a depth of less than approximately $250 \mathrm{ft}$, or unless by-product use can be found for the waste cooling water (irrigation, for instance).

An alternative cooling method for low humidity, temperature climates is shallow cooling ponds (lakes). Make up water would need to be slightly higher than for wet cooling towers, but by-product advantages are obvious compared to wet cooling towers. 


\subsection{PLANS FOR SUBSEQUENT QUARTER}

The next three months' activities will principally involve the following:

1. Completion of shallow (100 ft) wells (approximately 35).

2. Execution of formalized USGS-AEC agreement and resumption of USGS field work.

3. Revision of last year's formal plant construction-data sheet (AEC Schedule 44) and re-submission to AEC-HQ.

4. Conceptual design and preliminary estimates of costs for an organic fluid heat-exchanger for both a subcritical boiling and a supercritical fluid cycle. 


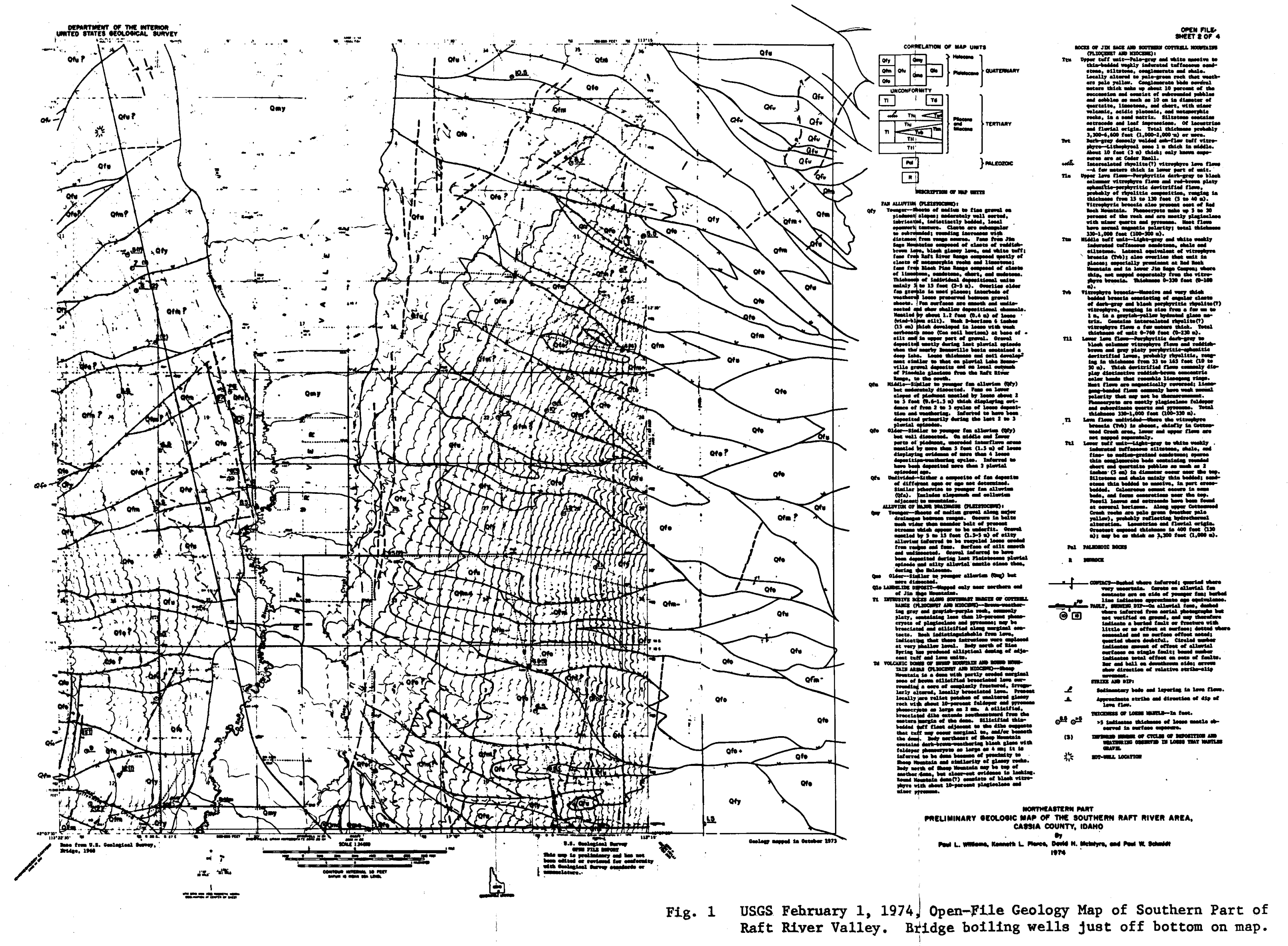




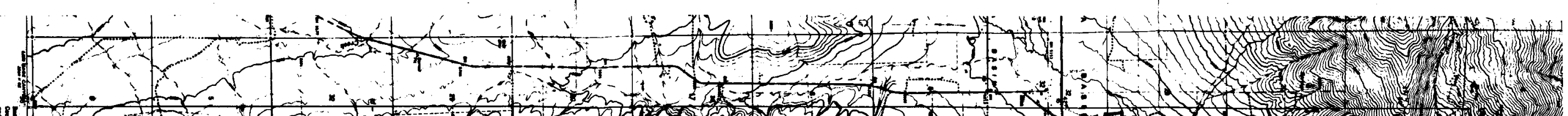

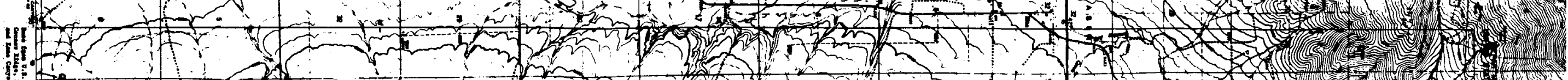

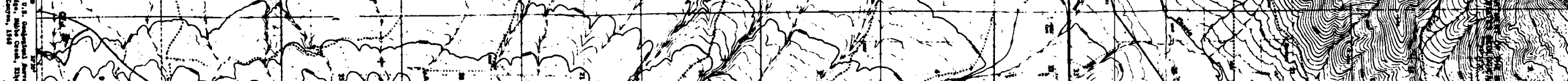

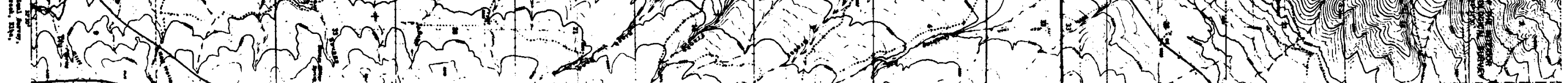

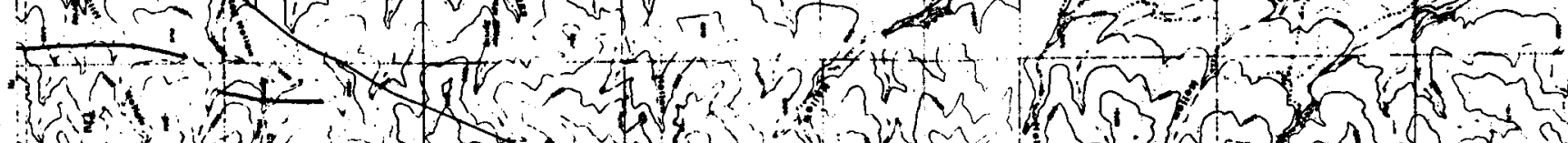

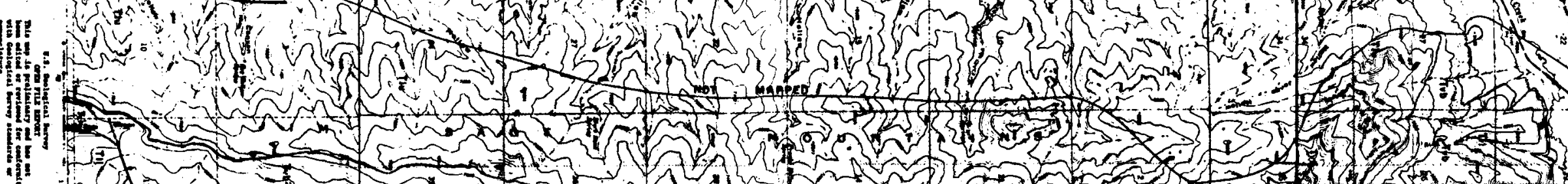

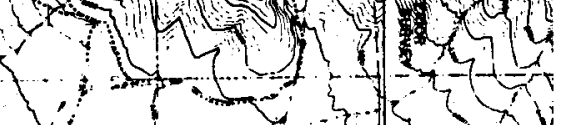

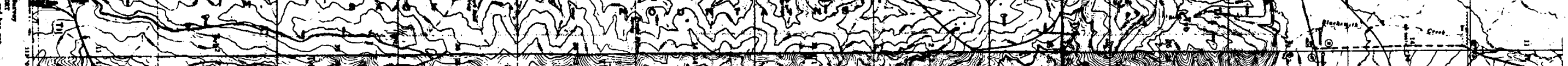
3.

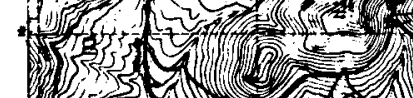
H.

2

1/

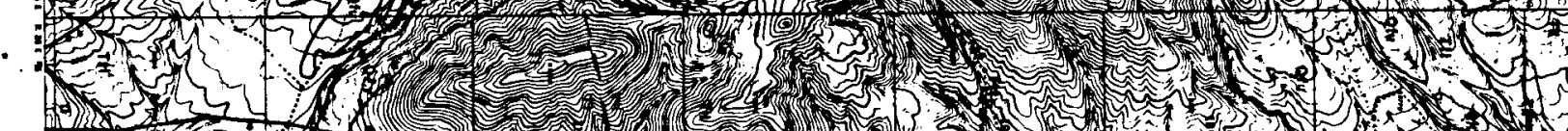

|f

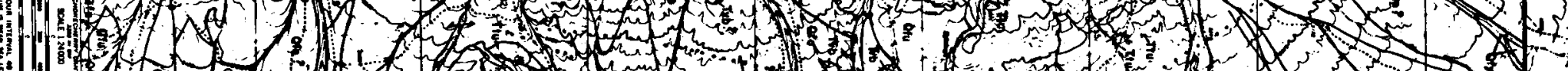

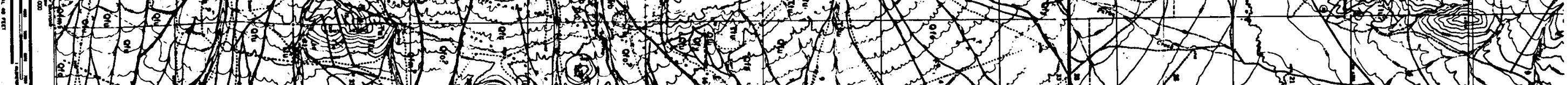

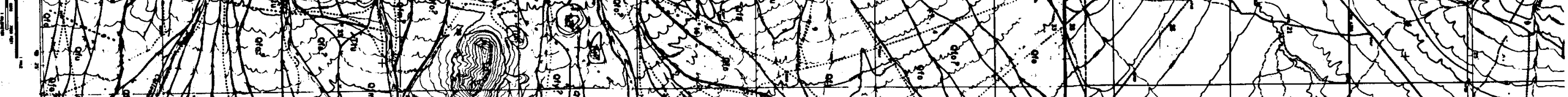

1. IIf 1 (2)

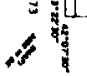

Fig. 2 USGS February 1, 1974, Open-File Geology Map of Raft River Valley West Side, Cotterrel ahd Jim Sage Range, and Almo Basin. Boiling corner of map. 


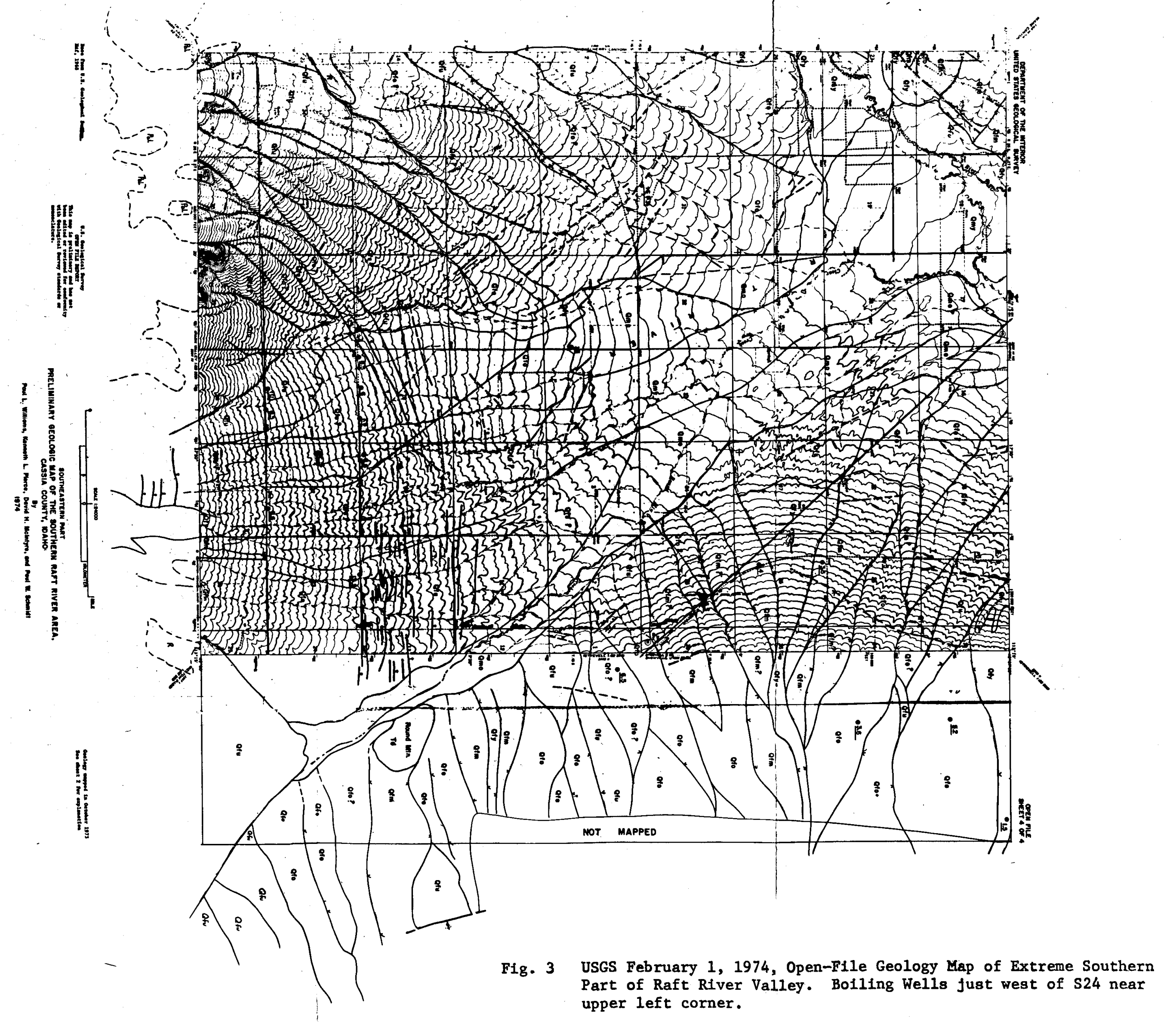




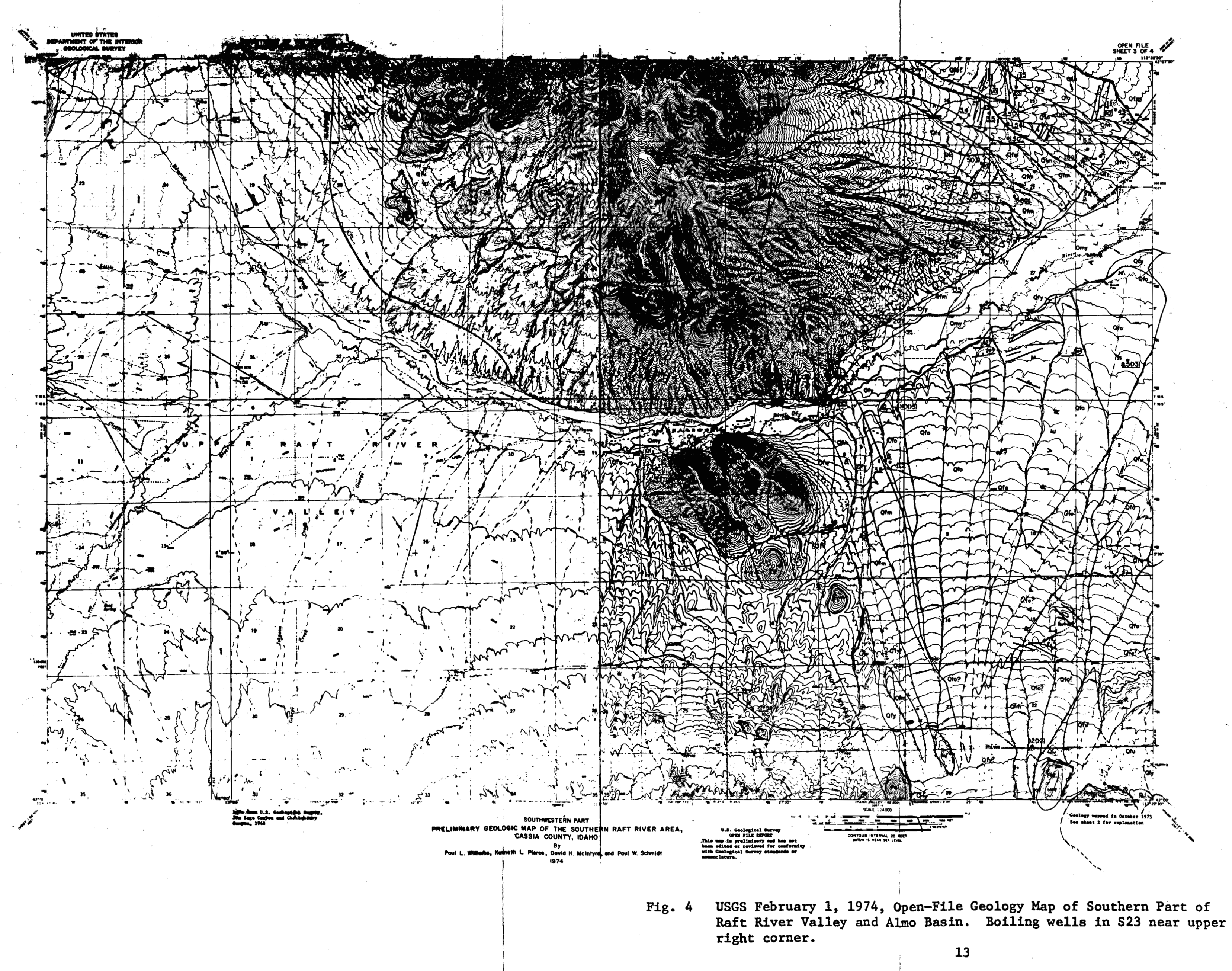




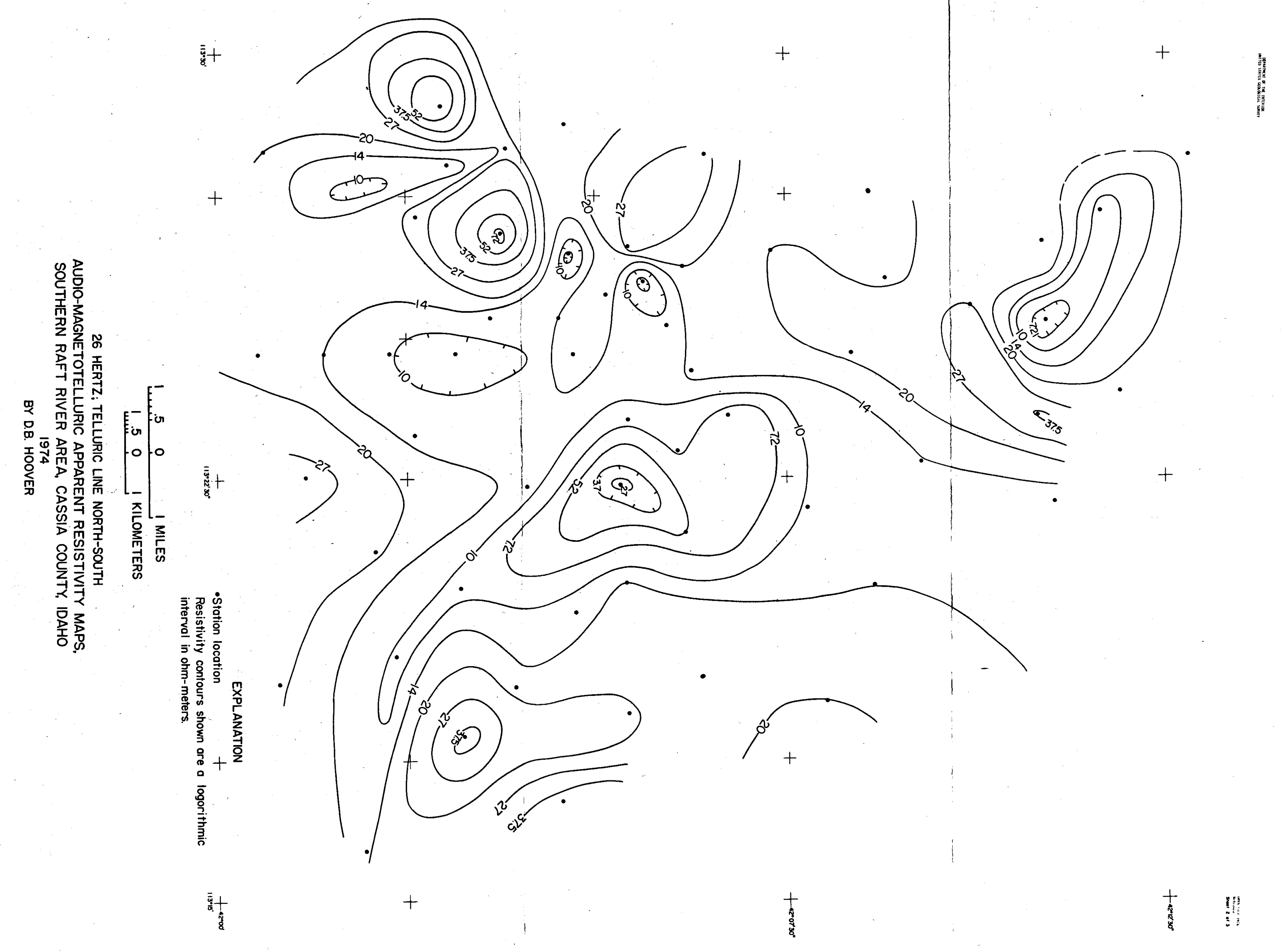

Fig. 5 (notes: Boiling wells near $113^{\circ} 23^{\prime} \mathrm{E}, 42^{\circ} 06^{\prime} \mathrm{N}, 26$ cycles gives $200 \mathrm{~m}$ skin depth at $4 \mathrm{ohm}$-meters, 1,000 m skin depth at 100 


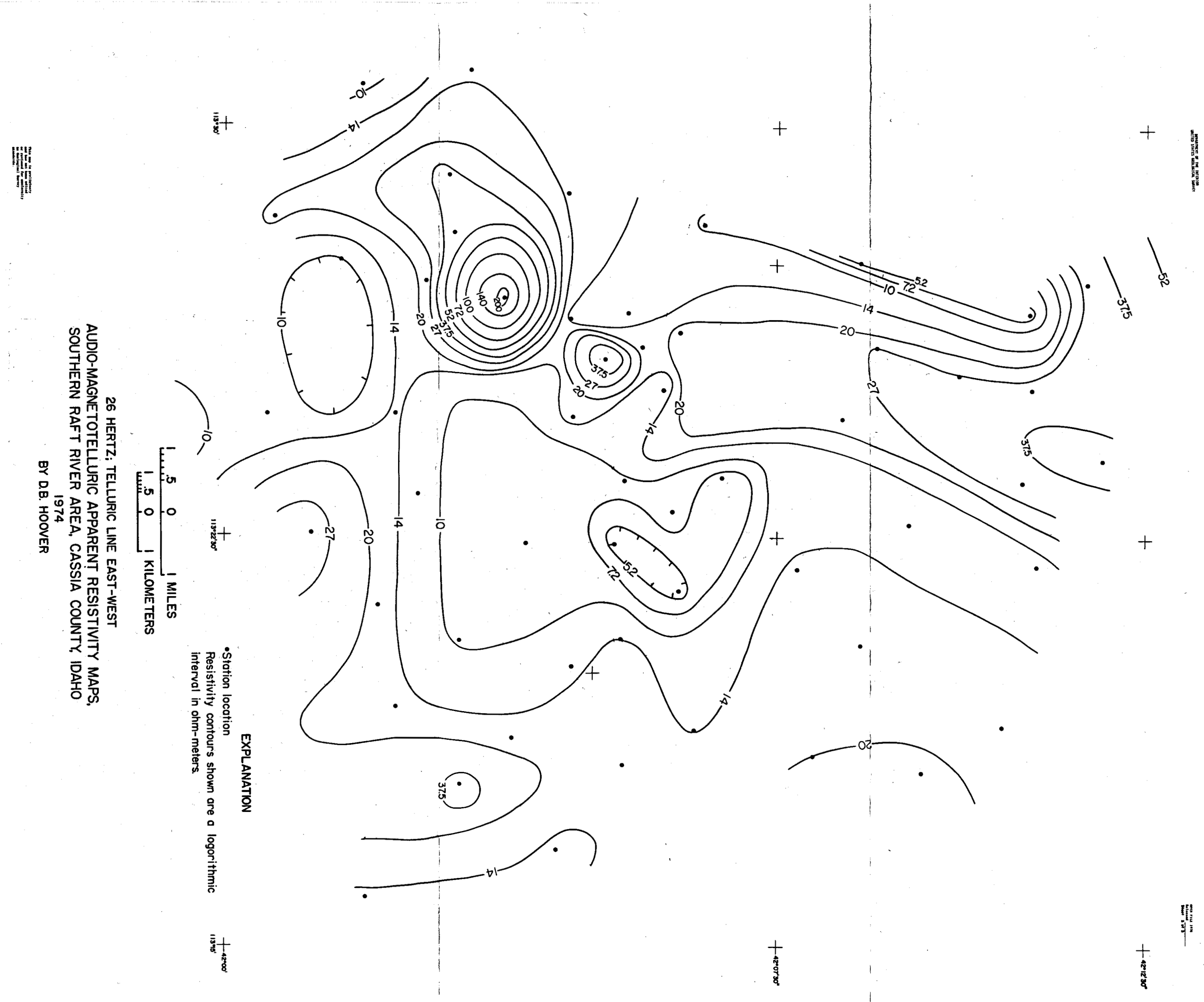

Fig. 6 (Notes: Boiling wells near $113^{\circ} 23^{\prime} \mathrm{E}, 42^{\circ} 06^{\mathrm{N}} \mathrm{N}, 26$ cycles gives $200 \mathrm{~m}$ skin depth at $4 \mathrm{ohm}$-meters, 1,000 m skin depth at 100 ohm-meters.) 


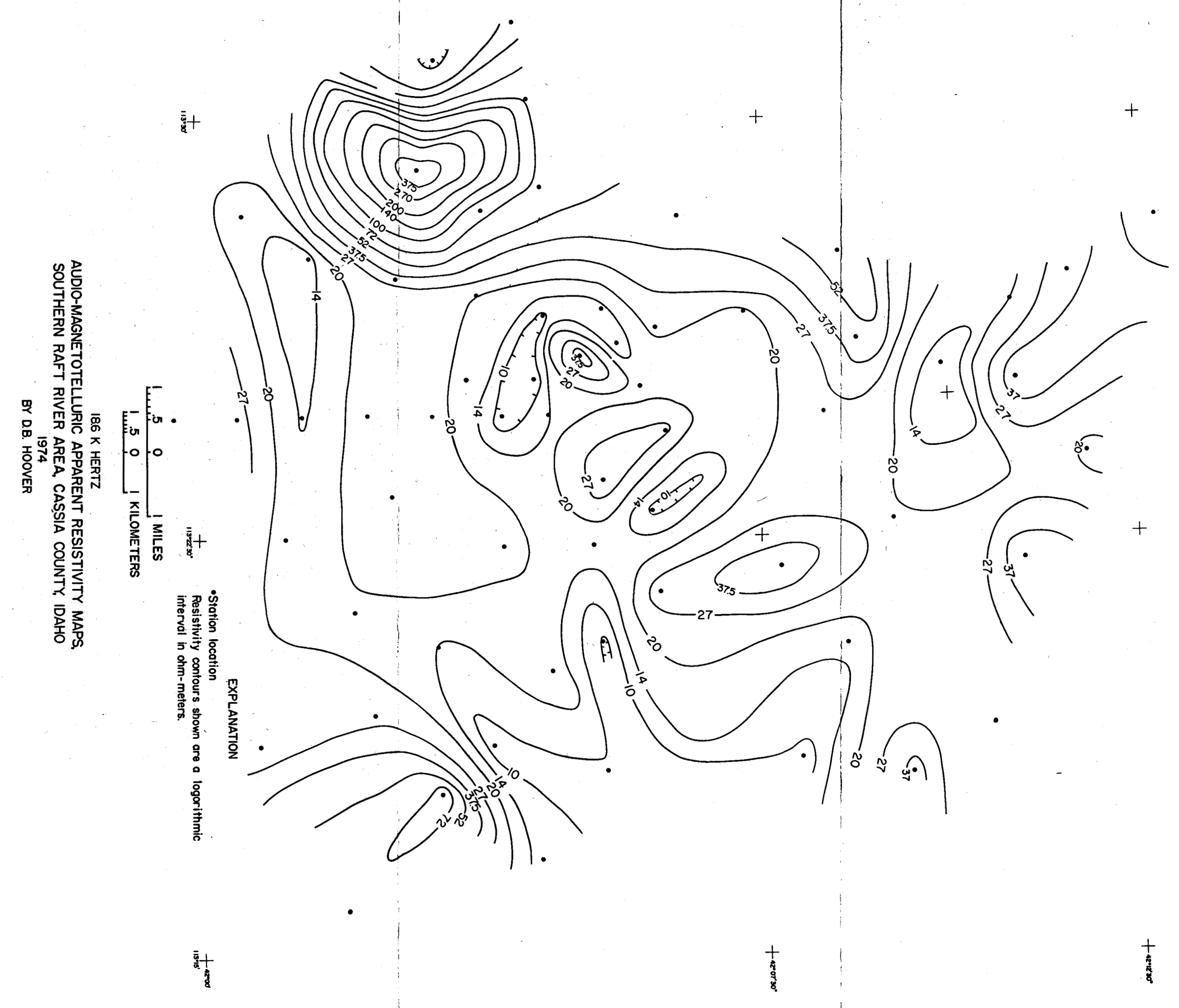

Fig. 7 (Notes: Boiling wells near $113^{\circ} 23^{\prime} \mathrm{E}, 42^{\circ} 06^{\prime} \mathrm{N}$. 18,600 cycles gives very shallow skin depth, 1.e., 47 meters at $100 \mathrm{ohm}$-meters.) 


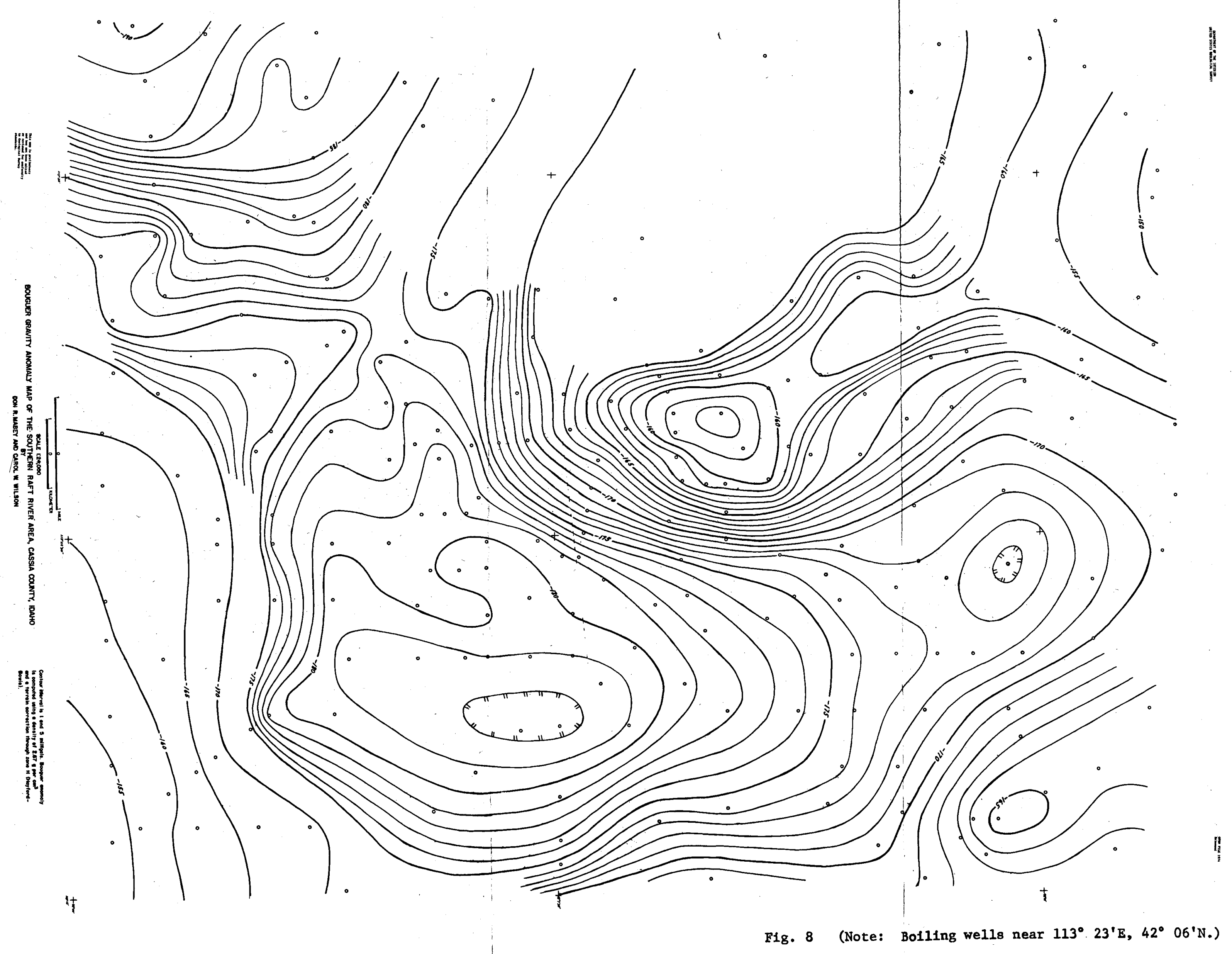




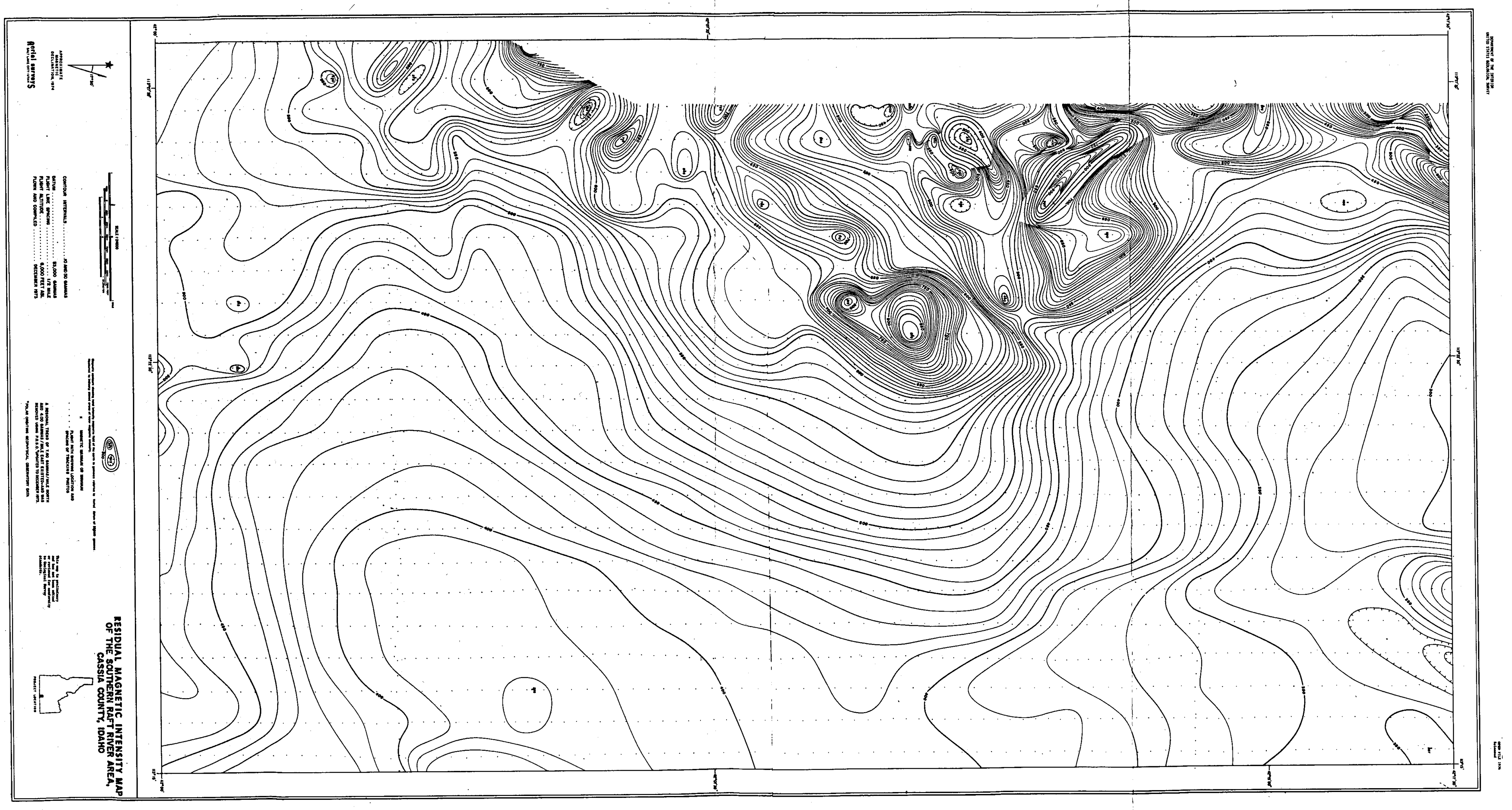

Fig. 9 (Note: Boiling/wells near $113^{\circ} 23^{\prime} \mathrm{E}, 42^{\circ} 06^{\prime} \mathrm{N}$. ) 


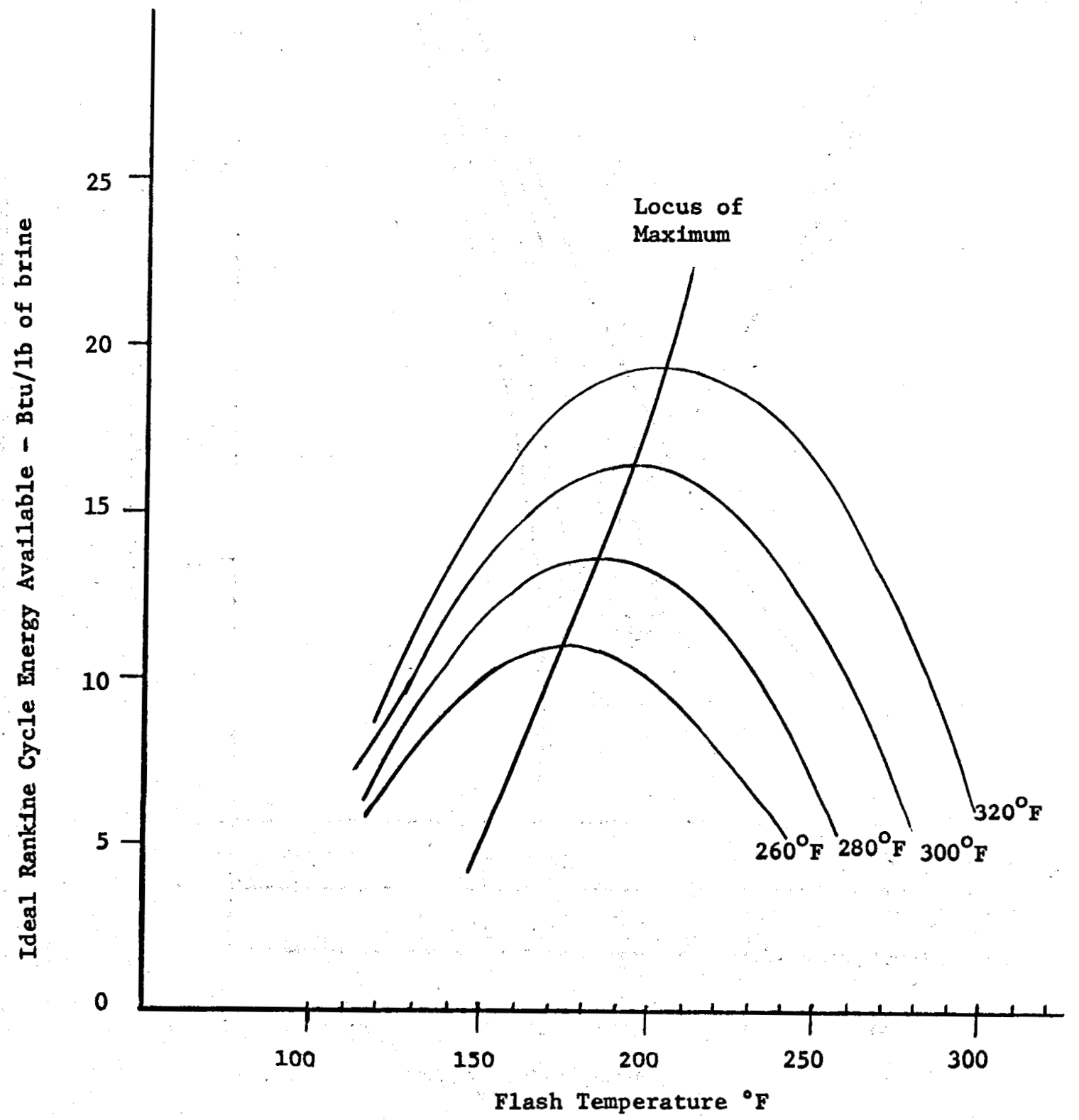

Fig. 10 Single flash Rankine cycle energy production from geothermal water of four different temperatures. Condenser pressure $1.5 \mathrm{in}$. HgA. No $108 s e s$ and $100 \%$ turbine efficiency assumed. 


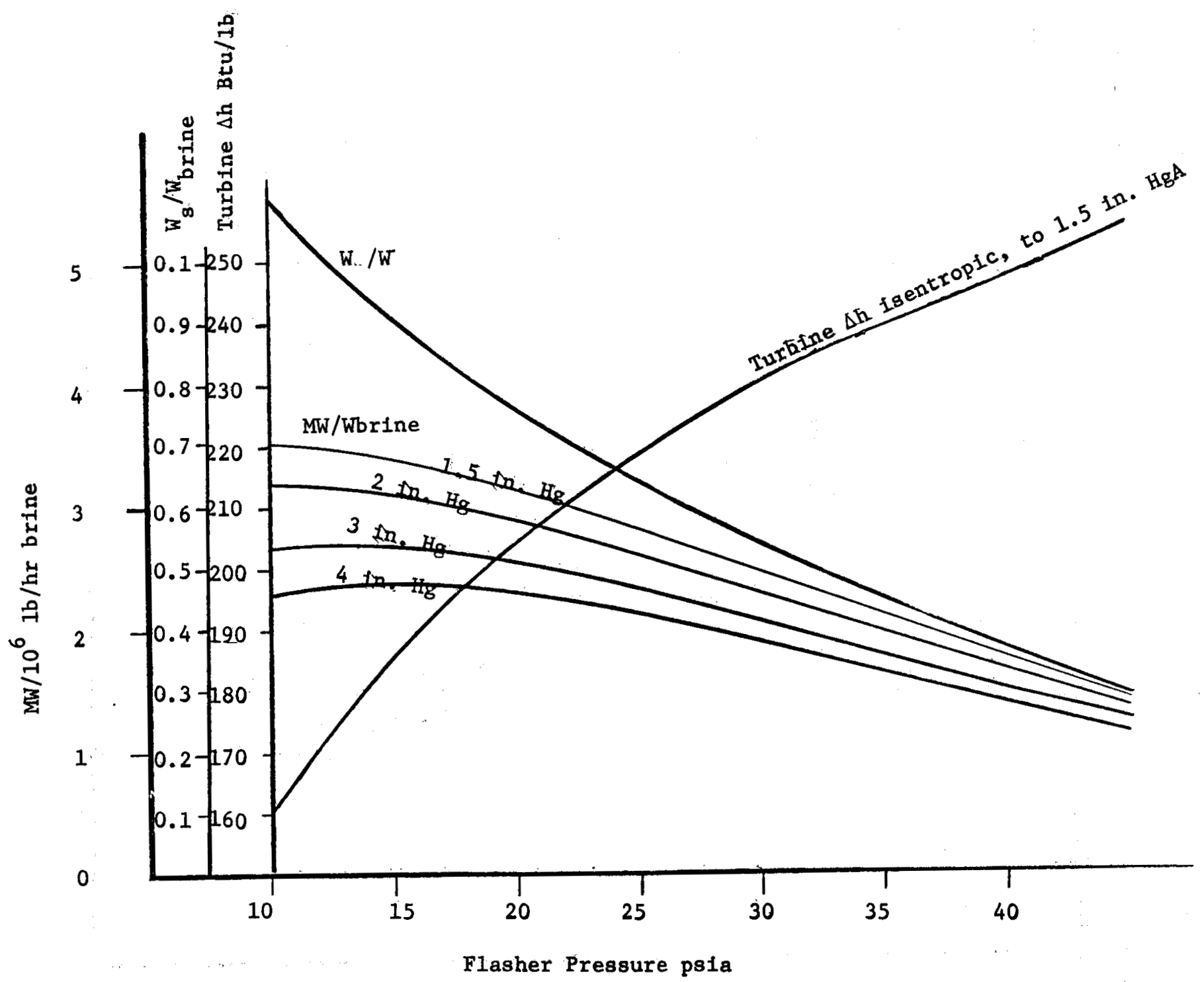

Fig. 11 Single stage steam power plant performance from $150^{\circ} \mathrm{C}$ geothermal fluld 


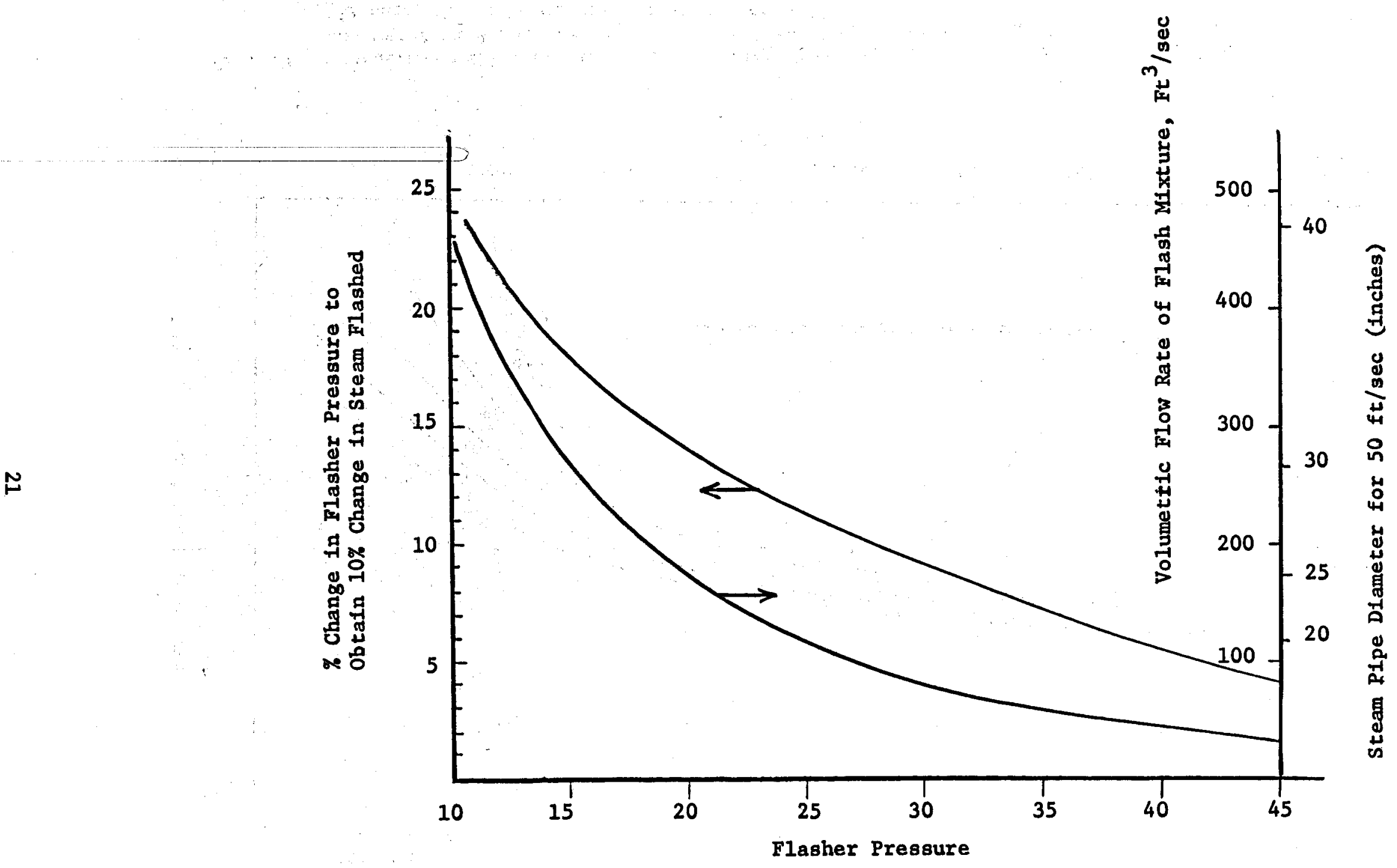

F1g. 1210 MW(e) single stage steam flash from $300^{\circ} \mathrm{F}$ geothermal fluld 


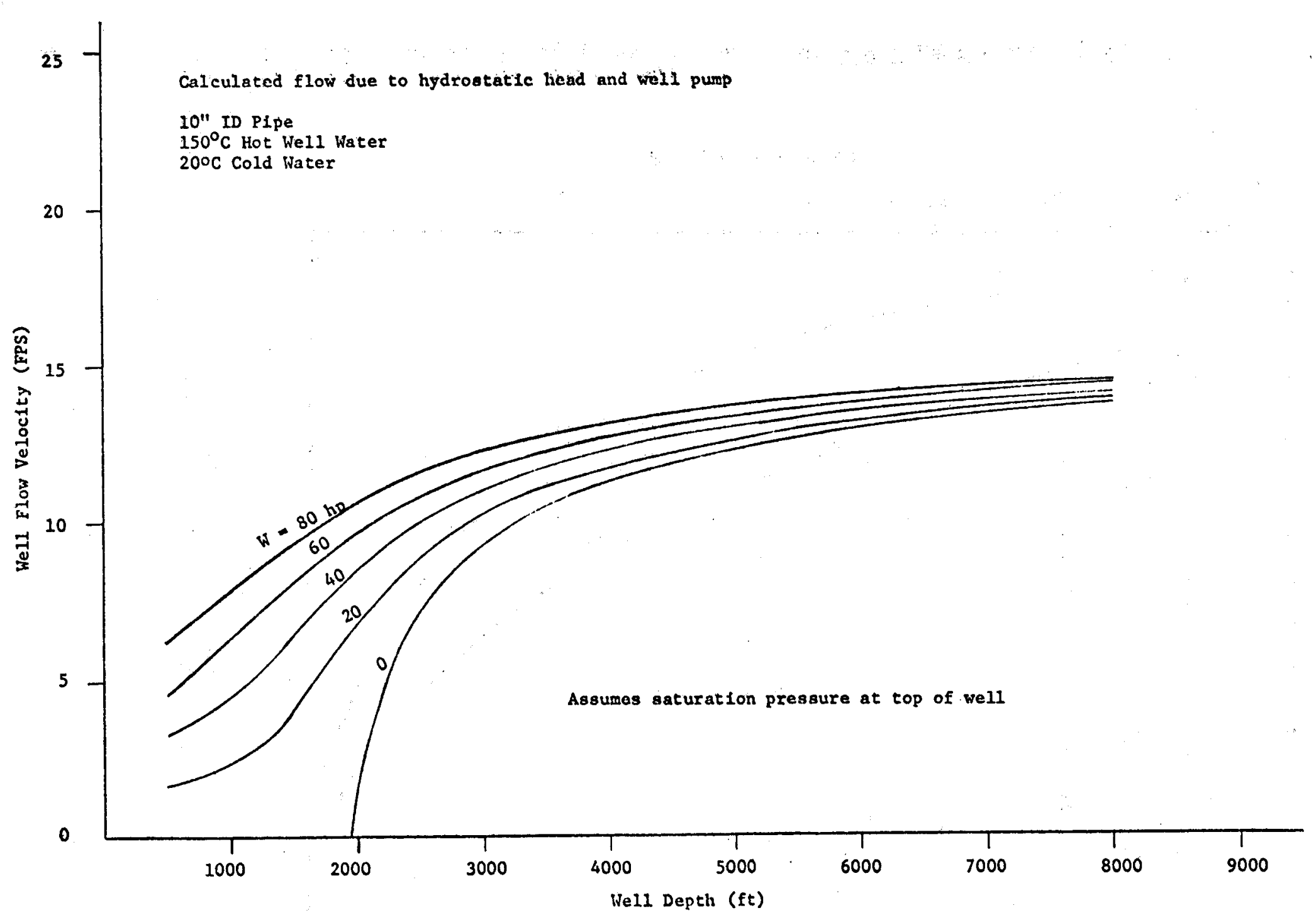

Fig. 13 Geothermal well flow increase resulting from down-hole pump. Note: $150^{\circ} \mathrm{C}\left(302^{\circ} \mathrm{F}\right)$ hot water will not pump from well of 1 ess than $1,950 \mathrm{ft}$ if saturation pressure (69 psia) is to be maintained at top of well. 


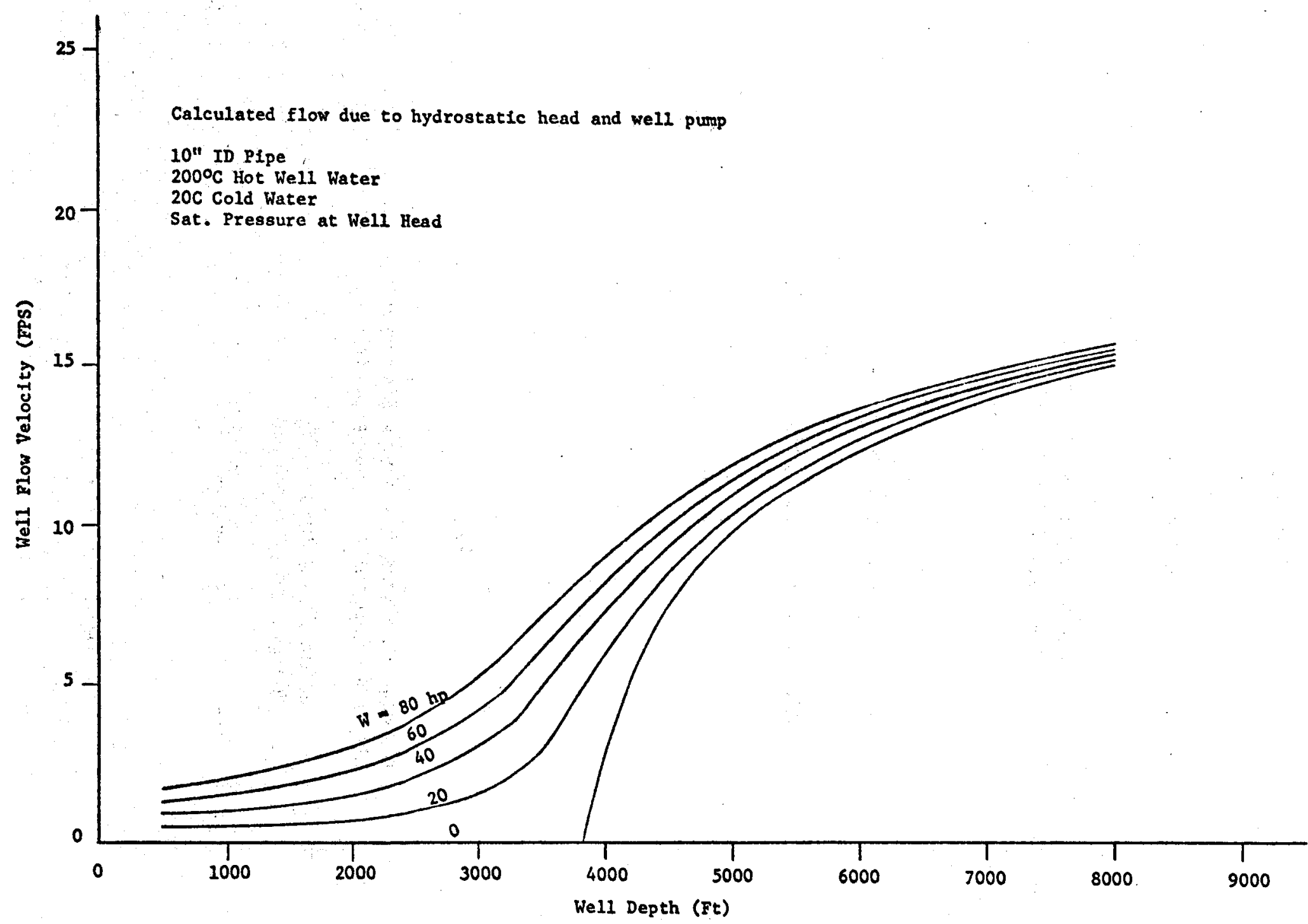

Fig. 14 Geothermal flow increase resulting from down-hole pump. Note: $200^{\circ} \mathrm{C}\left(392^{\circ} \mathrm{F}\right)$ hot water will not pump from well of less than $3,800 \mathrm{ft}$ if saturation pressure (226 psia) is to be maintained at top of well. 
APPENDIX I

FINAL REPORT

GEOLOGIC AND GEOPHYSICAL ASPECTS OF SITE SELECTION FOR

A GEOTHERMAL DEMONSTRATION PROJECT, RAFT RIVER, IDAHO

Submitted to

Idaho Nuclear Energy Commission

by

Clayton R. Nichols - Project Leader

James K. Applegate - Investigator

Boise State University

Department of Geology

March 12, 1974 
Through the support of the INEC, two Boise State University Department of Geology faculty members have participated in a project pertaining to planning and the interpretation of data from the Raft River geothemal area, Cassia County.

, the BSU investigators redirected their efforts to: 1) the acquisition and interpretation of other data useful to the Raft River project; 2) proposal development for other low temperature geothermal demonstration projects; 3) advising Aerojet Nuclear Company on the construction of electrical resistivity gear; and 4) the interpretation of USGS open file information after its release in February (1974).

(Editor's Note: The above page was partially abstracted from the original version.) 


\section{RESULTS OF THE INVESTIGATION}

Data Acquisition and Interpretation Independent of the USGS Projects:

Samples from two petroleum tests drilled in the Raft River were placed in the Boise State University Department of Geology's sample depository. Drilling time records (rate of penetration), mud logs and commerciallyprepared lithology logs were also given to BSU. Sample analysis for the "hot" well three miles south of Malta (Griffith-Wight No. 1, SENW Sec. 1, TI4S R26E) was completed by Miss Ann C ochrane, a student working under the direction of Nichols, utilizing microscopic techniques supplemented by $X$-ray diffraction analysis.

The samples indicated a section of volcanic tuffs, shales, siltstones and sandstones down to a depth of $5000 \mathrm{ft}$. From 5000 to 6000 feet, the proportion of sandstone vs. volcanic sediments increased. Carbonate rocks (limestones and dolomites) of probable Paleozoic age were dominant below 6000 feet.and continued to the bottom of the hole at 6787 feet. This thickness of relatively young volcanic and sedimentary valley fill in the Raft River Basin (5000-6000 feet) is in close agreement with our preconceived ideas of the depth of the basin.

The sediments encountered in the well near Malta are dominantly fine grained at depth. Calcite cementing is extensive. Zeolites (hydrated aluminum silicate minerals) have formed extensively in the deeper volcanic sediments as thermal alteration products of the volcanic glass. The presence of pyrite and cryptocrystalline quartz in some sample intervals may indicate the presence of thermal fluids and more detailed mineralogical work on the samples is planned. This information has been forwarded to Don Snodgrass of the Nevada. Test Site, Deep Drilling Operations Branch, for his use in estimating drilling costs in the Raft River Project. 
New Proposal Development:

Nichols, Applegate and Hollenbaugh of BSU and Mink, Idaho Bureau of Mines and Geology, prepared the geologic and hydrologic portion of "A Joint Proposal for a Demonstration Space Heating Project Involving Government-Owned Buildings at Boise, Idaho." This joint proposal from the state of Idaho and Aerojet Nuclear Company seeks AEC funding for the research and development of municipal space heating in Boise. Faculty released time for Nichols and Applegate made possible by the INEC Raft River grant was aiso utilized in the preparation of the Boise proposal during January prior to the release of the USGS open file reports on the Raft River project.

\section{Resistivity Equipment Construction:}

During November and December, 1973, Applegate cooperated with Miller and others at Aerojet Huclear in the construction of dipole-bipole resistivity gear to be used in the Raft River and other geothermal projects by BSU and ANC personnel. Working with plans provided by Applegate, the equipment has been completed with the exception of one part which is on order.

In dipole-bipole resistivity mapping, the apparent resistivity of an area is calculated and contoured as opposed to the standard DC deep resistivity measurements which are made along a line across the area of interest. The technique is thus complementary to audio-magnetotelluric apparent resistivity mapping, which is more of a reconnaissance tool. The dipole-bipole apparent resistivity mapping may indicate low resistivity areas present to depths of several thousand meters and is thus ideally suited to geothermal propecting. The same equipment may be used in other configurations, such as Wenner or Schlumberger electrode arrays for resistivity mapping, spontaneous potential (self potential of "SP") mapping, electromagnetic mapping (EM), etc. 
Equipment Functioning: The source box switches and rectifies the output from a generator, providing an assymmetrical "DC" signal. One purpose of the assymmetrical signal is to simplify the identification of the signal received at a receiver box. The receiver box measures the potential field caused by the exciting signal at discrete locations in the area of interest. This recorded measurement is combined with the input current and various geometric parameters to calculate an apparent resistivity.

Interpretation of the USGS Preliminary Open File Data:

Through an exceptional effort, the data obtained during the fall 1973 field program of the USGS in the Raft River Valley was released to open file status on February 1, 1974. Maps released include:

1. Preliminary geologic map of the southern Raft River area, Cassia County, Idaho by P.L. Will iams, Kenneth L. Pierce, David H. McIntyre and P.W. Schmidt. 4 sheets, scale 1:24,000.

2. Residual magnetic intensity map of the southern Raft River area, Cassia County, Idaho, by the U.S. Geological Survey. I sheet, scale 1:24,000.

3. Bouguer gravity anomaly map of the southern Raft River area, Cassia County, Idaho, by Don R. Mabey and Carol W. Wilson. 1 sheet, scale $1: 24,000$.

4. Audio-magnetotelluric apparent resistivity maps, southern Raft River area, Cassia County, Idaho, by D.B. Hoover. 3 sheets, scale 1:24,000.

The Geologic Maps: The maps reveal a more complex geologic situation than had previously been imagined for the Raft River Valley and adjacent mountain ranges. Earlier models of the basin had pictured it simply as a down-dropped block or graben structure between the Cottrell and Jim Sage Ranges to the west, the Black Pine Range to the east and the Raft River 


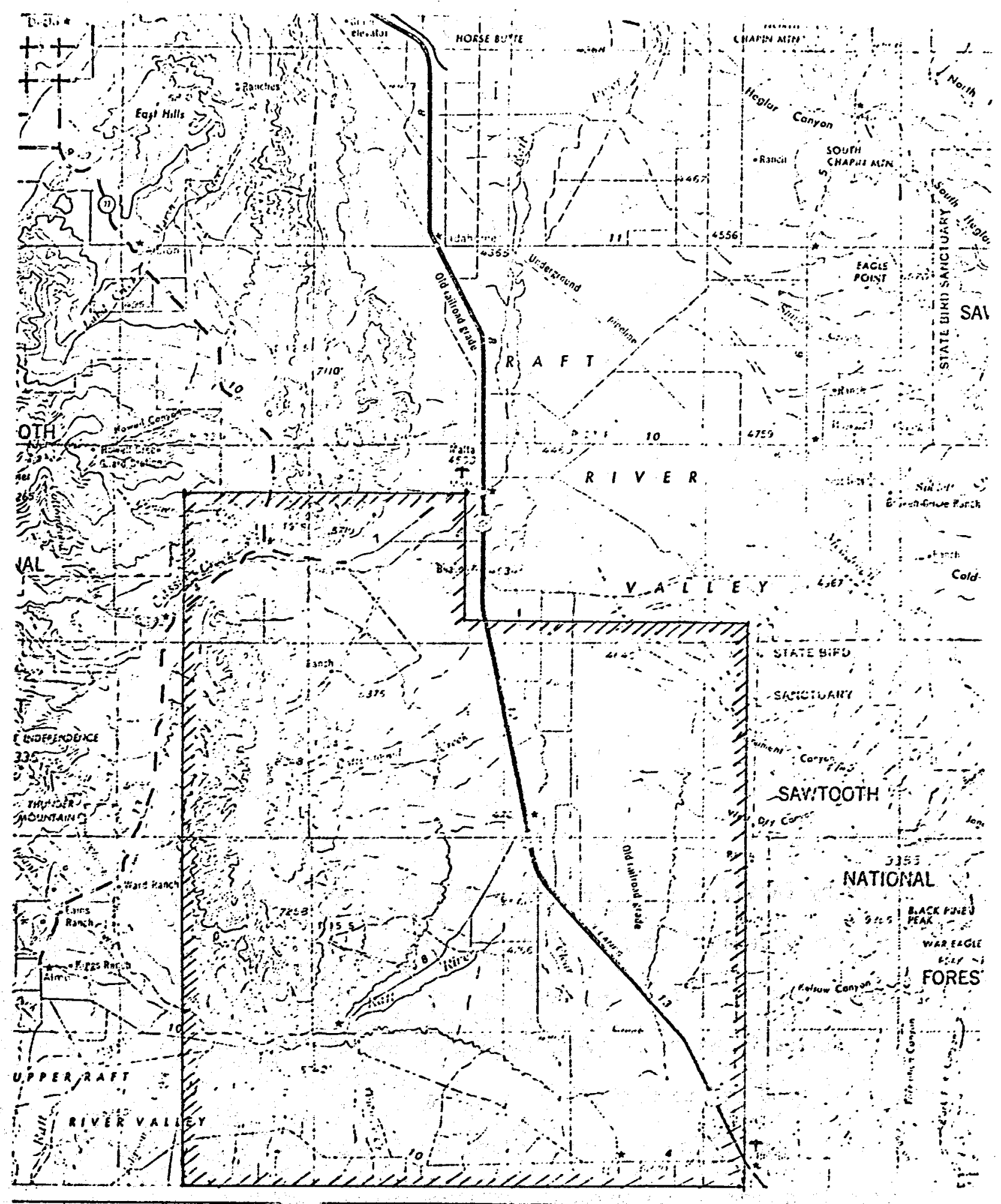

Figure 1

Area of geologic mapping, southern Raft River Valley 
Range to the south. The mapping by the Survey refines this model by indicating that the western ranges may have been upwarped rather than uplifted as simple, brittle blocks. These ranges and the important northsouth trending fault zones which parallel them have been the locus of extensive volcanic activity during Tertiary time. The youngest igneous unit mapped is a shallow intrusive body just north of Cassia Creek and Rice Spring, which was assigned a probable Miocene age. The age of this body (greater than seven million years) indicates that it and other known igneous rocks in the southern Raft River Valley are too old to still be cooling. The presence of this major vent zone along the western margin of the valley extending northward from the "narrows" is an important finding; nevertheless, as old zones of weakness may be reintruded from time to time. Sheep.Mountain is also an intrusive dome of Pliocene-Miocene age along this same trend. The dominant lava composition along the trend is rhyolitic, or $\mathrm{SiO}_{2}$-rich.

Fault trends mapped in addition to the north-south trend on the western margin of the valley include suspected major east-west strike-slip faults through the narrows and through the breach in the ranges west of Malta occupied by Cassia Creek. These faults are thought to have a dominant lateral or "sideways" component of movement rather than one side moving up, the other down. The area east of the narrows thus is the point of intersection of at least two major faulting trends and also is the site of the hottest water produced to date.

Much of the difficulty in the interpretation of the major geologic features is due to the veneer of alluvial fan deposits of Pleistocene age which cover the slopes in the critical areas. These have been painstakingly 
mapped by Williams et. al., and constitute most of the detail on the geologic maps. Nichols was able to confirm on the stereo aerial photo coverage of the southern Raft River Valley (provided by Aerojet Nuclear Company) the faults mapped by the USGS group. Based on "linears," or straight line trends in drainages, rock outcrops, etc., the Survey mapping of the numbers of small faults may even be conservative. Faults trending NW-SE are mapped in the area immediately SE of the hot wells east of the narrows. These may have an influence on the shallow hot water distribution as indicated by AMT data obtained by the Survey.

Residual Magnetic Intensity Map: A contour map showing variations in the residual magnetic intensity confirms the general geologic model discussed previously. Magnetic intensity measured at a particular location is influenced by the rock type(s) at depth. Some rock types, such as basalt, will yield abnormally high magnetic values. Sharp gradients in the data may indicate faulted contact of rocks with differing magnetic intensities. The data for the southern Raft River Valley contains several interesting anomalies in the Jim Sage Range and its margin near Sheep Mountain.

The 870 ganma positive anomaly east of Sheep Mountain may indicate buried igneous rock of a basic composition (basalt?) at shallow depth. This area could be separated by NE-trending normal faults from a lower portion of the basin to the south in the vicinity of Cranks! hot well. Other, more complex magnetic anomalies near the north end of the Jim Sage Range may also indicate igneous intrusive bodies at depth.

Bouguer Gravity Anomaly Map: This map shows variations in gravity measured in milligals after corrections for elevation are applied. Differ- 
ent rock types have differing densities, and these differences may be detected through their influence on the measured values of gravity over an area. High negative values on a Bouguer gravity map in an area like the Raft River Valley indicate relatively deep, low density fill material, whereas the denser marginal rock types will yield lower negative values. The gravity map thus generally reflects the configuration of the basin at depth, and sharp gradients may indicate faulting. The major faulting discussed previously is all supported by the gravity data. Especially well developed is the EW trend through the narrows. A gravity "high" is centered just west of the magnetic anomaly near Sheep Mountain. Based on the gravity mapping, the deepest portion of the southern Raft River Basin is the region just east of Cranks' hot well.

Audio-magnetotelluric Apparent Resistivity Maps, Southern Raft River Area: This method is a relatively recent innovation which involves measurements in the audio range of orthagonal components of the horizontal electric and magnetic fields induced by natural primary sources rather than by a DC input. These "natural" sources are atmospheric fluctuations of the electromagnetic field at frequencies of from 1 to $10^{5}$ hertz caused by lightning discharges at great distances. Observations of the induced electromagnetic field intensity are averaged over a period of time at each of a range of frequencies, and one component of the $E$ field is simultaneously recorded with coils arranged along NS and EW lines. At $2 E \mathrm{~Hz}$, for example, two maps of apparent resistivity are produced: one for a NS line and another for an EW line. The depth to which the resistivity is "seeing" is a function of the frequency according to the relationship: 


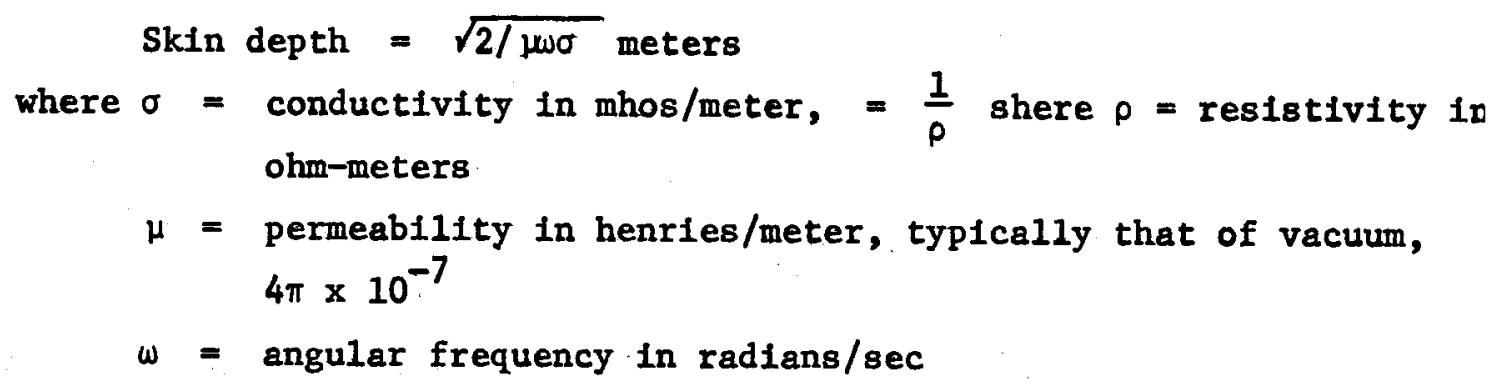

and skin depth - effective depth of penetration for the constants used by the Survey, the relationship simplifies at $26 \mathrm{~Hz}$ to:

Skin depth $=99 \sqrt{\rho}$

where $\rho$ is the observed apparent resistivity.

A few trial substitutions will indicate that the depth of penetration is very shallow at $26 \mathrm{~Hz}$ for areas of low resistivity. A value of $4 \mathrm{ohm}$ meters yields a depth of $198 \mathrm{~m}$. This does not imply that the low resistivity is confined to shallow depths, but rather that the measured resistivity values reflect only penetration to shallow depths.

Apparent resistivity "lows" were indicated on the $26 \mathrm{~Hz}$ maps corresponding to several of the known hot water occurrences. Most notable of these is the $2.7 \mathrm{~Hz}$ anomaly centered 0.5 miles SE of Cranks' hot well. Resistivity contours through the narrows also reflect general trends on the gravity and magnetic maps. Subsurface structures will affect values through their control of porosity at depth. Areas of low apparent resistivity, such as the Cranks' well anomaly, should be investigated, utilizing deep resistivity techniques.

\section{CONCLUSIONS}

The extensive investigations undertaken to date by the Geologic Survey and the release of deep well data from wildcat tests in the Raft River Basin allow a refinement of the earlier "simple" models of the Raft River Valley. The Jim Sage Range on the western margin of the valley is faulted and crossfaulted, domed upward and intruded throughout its NS length. The thermal 
water occurring along this valley in numerous deep wells may rise at a number of locations along the NS fault trend where it is cross-faulted, or it may be associated with only a few locations of especially intense faulting and be "spreading out" into aquifers through which it is widely distributed. The exceptionally carbonate-rich geochemistry of the water from Cranks' well may reflect the water's circulation down to depths where it contacts the carbonate rocks encountered at a depth of 6000 feet near Malta. Deep circulation, heating and the rise of fluids is still best evidenced in the downfaulted area east of the narrows. A.dditional deep resistivity should be conducted in the vicinity of the anomalies detected southeast of the hot vells.

The next petroleum test (which is scheduled to begin drilling within the next three weeks) will be sited close to the critical area east of the narrows which contains the hot wells. It is south of the deepest portion of the basin and will probably be structurally "high" relative to the Malta test. The temperature data and stratigraphic section revealed by this well may provide our best evidence to date of the geothermal potential of the southern end of the valley.

The samples from the Malta wildcat test indicate a predominantly volcanic tuff, siltstone, shale and sandstone section to a depth of 5000 feet. The limestones and dolomites of Paleozoic age below the younger valley fill may provide a reservoir for thermal fluids below 6000 feet in the deeper portions of the basin. 


\section{APPENDIX II \\ MULTIFLASH STEAM CYCLE PARAMETRIC STUDY FOR GEOTHERMAL POWER PLANT}

The following table and figure are extracted from a report submitted by Dr. D. T. Neill of Idaho State University. In a cooperative effort with the AEC's Idaho Geothermal R\&D Project, this study was supported by the Idaho Nuclear Energy Commission.

As noted in the main body of this report, the multiple flash situation more nearly approaching the infinite small step. reyersible situation produces the maximum plant output. However, the gain to be realized over an optimized two stage flash (see for instance Case No. 7, though it is not necessarily optimized) probably does not exceed 15\%. Yet hardware cost differences would be enormous. It should also be noted that hardware costs for the Case No. 7 with a 4 psia second stage flash probably far exceeds those for Case No. 5 with second stage flash at 10 psia. Yet the plant output increase is only $11 \%$.

For Purposes of conversion:

$10,000 \mathrm{gpm}$ is approximately $4.6 \times 10^{6} \mathrm{lb} / \mathrm{hr}$ of geothermal fluid flow $\left(302^{\circ} \mathrm{F}, 150^{\circ} \mathrm{C}\right)$

$20 \times 10^{6} \mathrm{Btu} / \mathrm{hr}$ turbine work is $5.86 \mathrm{MW}$.

For comparison, the Case No. 7 output is nearly double that of the idealized Freon 11 and Freon 21 subcritical boiling cycles of reference document ANCR-1138 (A Low Temperature Demonstration Power Plant in the Raft River Valley), but is substantially lower than the output of the highly idealized Freon 12 supercritical cycle. 


\section{TABIE 1}

TURBINE WORK FROY MULTIFLASII STEAY GENERATORS

Inlet Conditlons: $1.0 \times 10^{6} \mathrm{lb} / \mathrm{hr}$ of saturated, gcothermal water $\left(302^{\circ} \mathrm{F}, 69 \mathrm{ps} 1 \mathrm{a}\right)$

Turbine efficiency: 757.

Turbine discharge conditions: $79^{\circ} \mathrm{F}, 1$ in $\mathrm{llg}$ A (0.5 psia)

\begin{tabular}{|c|c|c|c|c|}
\hline $\begin{array}{l}\text { Case } \\
\text { Ro. } \\
\end{array}$ & $\begin{array}{l}\text { No. Flash } \\
\text { Starocs }\end{array}$ & $\begin{array}{c}\text { Flash } \\
\text { Pressurcs (nsia) }\end{array}$ & $\begin{array}{l}\text { Stcan Hanss } \\
\text { F low } \times 10^{-4} \\
(1 h / h r)\end{array}$ & $\begin{array}{c}\text { Turbine Work from } \\
\text { Flash Stage } \times 10^{-6} \\
\text { (btu/hr) }\end{array}$ \\
\hline $1 *$ & 1 & 10.0 & 11.4 & 15.4 \\
\hline 2 & 1 & 8.7 & 11.8 & 15.2 \\
\hline$-\frac{3}{4}$ & $-\frac{1}{2}-\cdot$ & 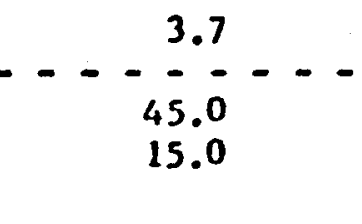 & $-\frac{15.4}{-. .}-$ & $\begin{array}{c}14.8 \\
\frac{-.2}{6.2} \\
\frac{9.9}{16.1}\end{array}$ \\
\hline 5 & 2 & $\begin{array}{l}30.0 \\
10.0\end{array}$ & $\begin{array}{l}5.7 \\
5.7\end{array}$ & $\begin{array}{r}10.7 \\
7.2 \\
17.9\end{array}$ \\
\hline 6 & 2 & $\begin{array}{l}26.0 \\
15.0\end{array}$ & $\begin{array}{l}6.7 \\
2.9\end{array}$ & $\begin{array}{r}12.2 \\
4.5 \\
16.7\end{array}$ \\
\hline $7 *$ & 2 & $\begin{array}{r}21.5 \\
4.0\end{array}$ & $\begin{array}{l}7.7 \\
7.1\end{array}$ & $\begin{array}{r}13.2 \\
6.9 \\
\end{array}$ \\
\hline- & $-\frac{-}{3}$ & $\begin{array}{c}-\ldots . . \\
60.0 \\
42.0 \\
3.7\end{array}$ & $\begin{array}{c}--.-\cdots \\
1.0 \\
2.5 \\
11.6\end{array}$ & $\begin{array}{c}-\ldots-1 \ldots \\
2.2 \\
5.1 \\
\frac{11.0}{18.3}\end{array}$ \\
\hline 9 & 3 & $\begin{array}{r}60.0 \\
30.0 \\
3.7\end{array}$ & $\begin{array}{l}1.0 \\
4.4 \\
9.5\end{array}$ & $\begin{array}{l}2.2 \\
8.3 \\
9.0 \\
19.5\end{array}$ \\
\hline 10 & 3 & $\begin{array}{r}60.0 \\
16.0 \\
3.7\end{array}$ & $\begin{array}{l}1.0 \\
8.7 \\
5.4\end{array}$ & $\begin{array}{r}2.2 \\
13.6 \\
5.1 \\
20.1\end{array}$ \\
\hline 11 & 3 & $\begin{array}{l}45.0 \\
26.0 \\
15.0\end{array}$ & $\begin{array}{l}3.0 \\
3.4 \\
2.9\end{array}$ & $\begin{array}{l}6.2 \\
6.2 \\
6.5 \\
16.9\end{array}$ \\
\hline
\end{tabular}


Table 1 Continued

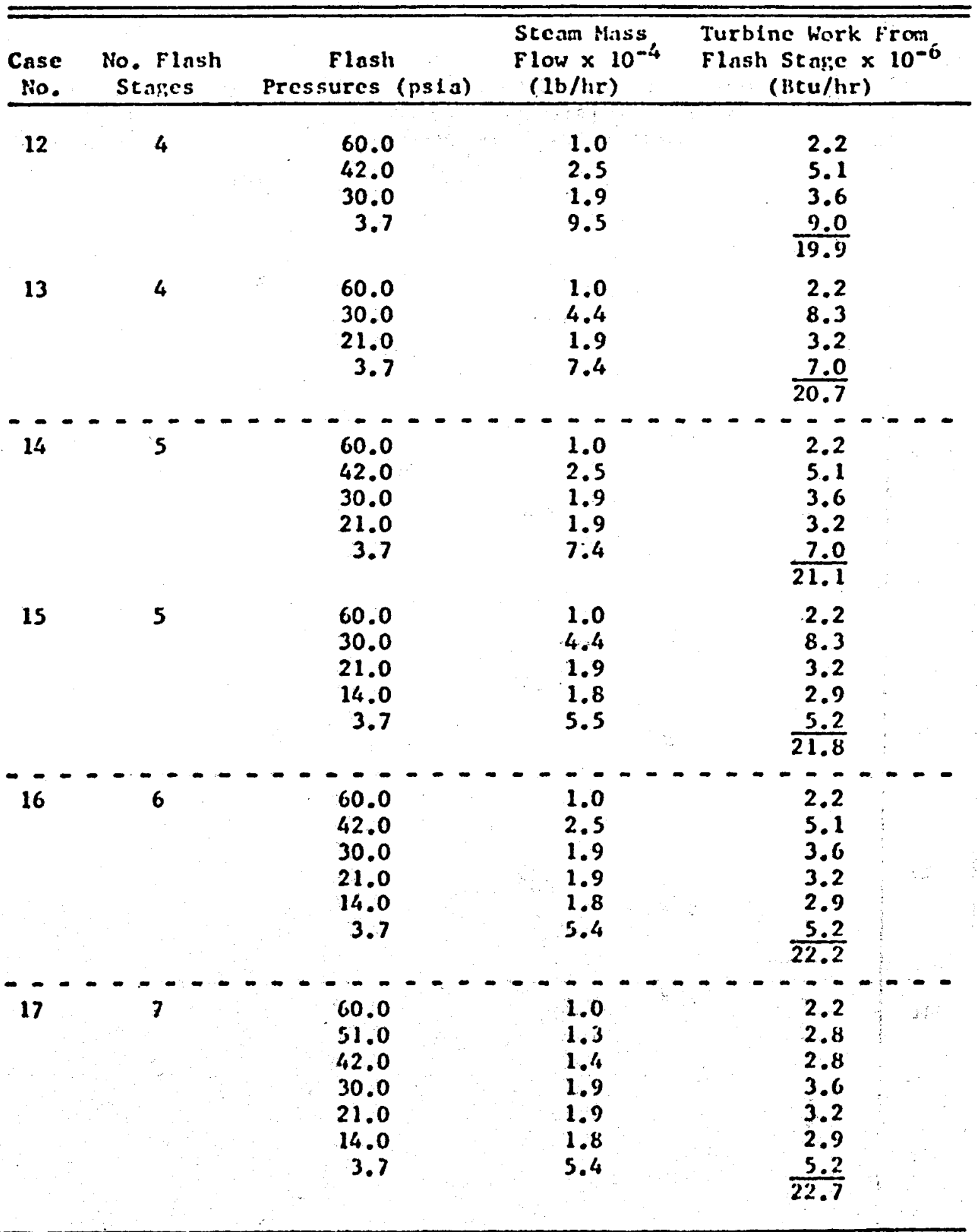

*flash condltion: which produce miximun turblne work for the number of seasses. 


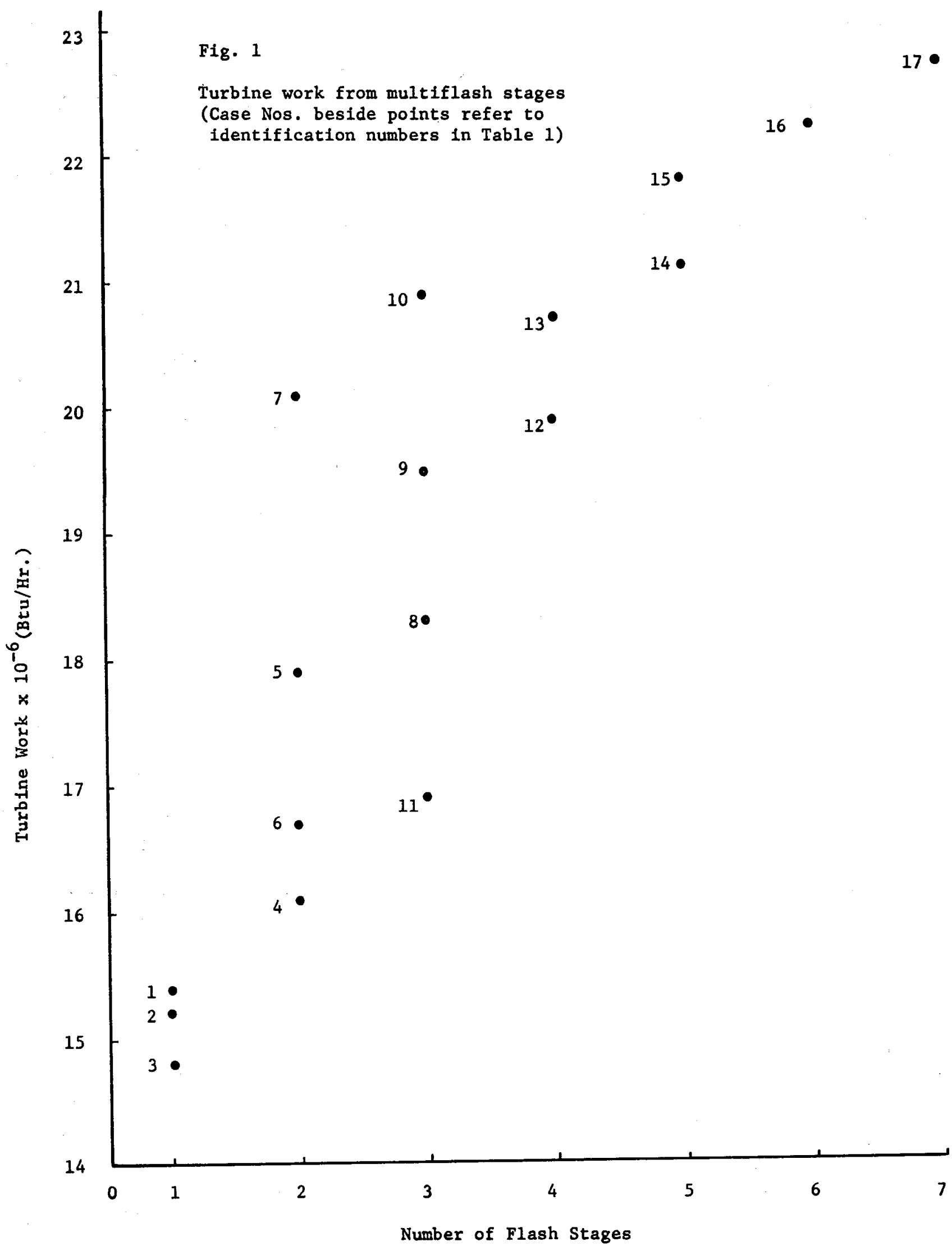

